\title{
Pericardial Leiomyoma
}

National Cancer Institute

\section{Source}

National Cancer Institute. Pericardial Leiomyoma. NCI Thesaurus. Code C6743.

A benign smooth muscle neoplasm arising from the pericardium. It is characterized by the presence of spindle cells with cigar-shaped nuclei, interlacing fascicles, and a whorled pattern. 